\title{
Investigation and performance evaluation of transmitter configurations in urban environment for next generation of wireless communications
}

\section{Дослідження та оцінка продуктивності конфігурацій передавачів у міському середовищі для наступного покоління бездротового зв'язку}

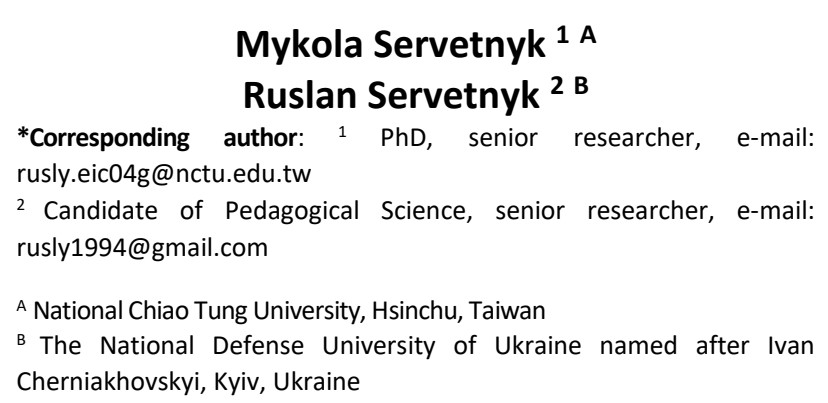

Ruslan Servetnyk 2 B

\author{
*Corresponding author: $1 \mathrm{PhD}$, senior researcher, e-mail: \\ rusly.eic04g@nctu.edu.tw \\ 2 Candidate of Pedagogical Science, senior researcher, e-mail: \\ B The National Defense University of Ukraine named after Ivan \\ Cherniakhovskyi, Kyiv, Ukraine
}

\section{Микола Серветник ${ }^{1 \text { A }}$ \\ Руслан Серветник 2 В}

*Corresponding author: ${ }^{1} \mathrm{PhD}$, старший науковий співробітник, e-mail: rusly.eic04g@nctu.edu.tw

${ }^{2}$ кандидат педагогічних наук, старший науковий співробітник центру, еmail: rusly1994@gmail.com

А Національний університет Чіао Тунг, Сінчжу, Тайвань

в Національний університет оборони України імені Івана Черняховського, Київ, Україна

Received: February 1, 2022 | Revised: February 22, 2022 | Accepted: February 28, 2022

DOI: $10.33445 /$ sds.2022.12.1.7

Purpose: Research highlights the impact of ISD, antenna array size, and operating frequency on link budget, coverage, and achievable rate. Furthermore, the existence of an optimal combination of transmitter parameters is shown.

Findings: In this work impact of inter-site distance, antenna array size, and the center frequency of the transmitter on system performance is evaluated for the urban macrocellular environment.

Practical implications (if applicable): The work fills the gap between theoretical results for transmission design and experimental measurements for mmWave channels.

Originality/Value: Useful guidelines for evaluation of QoS for 5G NR benefit further research to be done in this area.

Paper type: practical.

Key words: millimeter wave, 5G New Radio, urban macro.
Мета роботи: Дослідження підкреслюють вплив ISD, розміру антенної решітки та робочої частоти на бюджет каналу, покриття та досяжну швидкість. Крім того, показано існування оптимальної комбінації параметрів передавача.

Результати дослідження: У цій роботі оцінюється вплив відстані між вузлами, розміру антенної решітки та центральної частоти передавача на продуктивність системи для міського макростільникового середовища.

Практична цінність дослідження: Робота заповнює розрив між теоретичними результатами для проектування передачі та експериментальними вимірюваннями для каналів мм хвиль.

Оригінальність/Цінність дослідження: Корисні рекомендації щодо оцінки QoS для 5G NR принесуть користь подальшим дослідженням у цій галузі.

Тип статті: практична

Ключові слова: міліметрова хвиля, нове радіо 5G, міський макрос.

\section{Introduction}

Millimeter-wave (mmWave) communications, together with multiple-input multiple-output (MIMO) antennas technologies, have shown its great potential to deal with the increasing data requirements for fifth-generation (5G) mobile networks (Mumtaz S., 2018). It is a known fact that the mmWave channel suffers from high path loss (3GPP Radio Access Network Working Group; MacCartney G.R.), especially for diffraction and penetration. These losses are compensated by antenna array gain using MIMO techniques such as beamforming (Roh W., 2014). An increasing number of antennas allows the transmitter to concentrate more power towards the mobile stations (MSs) and hence improve quality-of-service (QoS). Moreover, to meet the demand of the increased wireless traffic, mobile operators deploy a large number of small cells in densely populated regions (Ge X., 2016). In literature, this environment is often referred to as an urban macrocellular (UMa) [2] and poses a severe challenge for network design. A standard measure for characterizing the site density in a cellular network is inter-site-distance (ISD) (Landström A., 2012), i.e., a distance between two closest base stations (BSs). Decreasing ISD improves coverage at the cost of increased 
interference, which, in return, degrades the signal.

Studies on ultra-dense mobile networks planning for mmWave transmitters equipped with a large number of antennas are still at the beginning stage. Initial research conducted in this area includes network architecture and cellular densification limits. An algebraic approach for area spectral efficiency cellular networks for equally spaced BSs with small reuse distance was presented in (Hou H.-A., 2017). Similar work, for coverage and average capacity in a cellular network, but with stochastic BS placement following stochastic geometry models was done in (Andrews J., 2011; Kountouris M., 2017). While being theoretically informative, works in these fields rarely include the impact of a real-world scenario such as the presence of infrastructure, street canyons, the difference in BSs and MSs heights, blockage, etc.

The study on mmWave originated by work in (Rappaport T. S., 2013), opened the field for massive MIMO beamforming. MmWave massive MIMO is a promising candidate technology for exploring new frontiers for next-generation cellular systems, starting with $5 G$ networks. It benefits from the combination of sizeable available bandwidth and high antenna gains. For more details, we suggest reading the survey (Busari S. A., 2017).

To summarize, there is an abundant number of works regarding experimental measurements for mmWave communications and theoretical aspects of massive MIMO and network densification. These make it imperative to conduct practical evaluations for the abovementioned transmitter configurations in a dense urban environment.

\section{Data and methods}

In the section below, the system model and performance evaluation metrics are presented. First, we introduce and motivate the choice of UMa scenario, channel model, and array size used in evaluations. Next, guidelines of performance evaluation, such as coverage, signal-to-interferenceplus-noise ratio (SINR), and throughput, are introduced.

Remark. This work focuses on the UMa scenario; however, the methods and tools presented below are applicable to other scenarios.

Urban macrocellular. In typical UMa, the UE is located outdoors at street level, and the fixed BS is at the level of surrounding building heights. As for propagation conditions, non- or obstructed line-of-sight are frequent cases, since the street level is often reached by single diffraction over the rooftop. The building blocks can form either a regular grid or have more random locations.

The dominant feature of the propagation environment is path (propagation) loss (PL). It is defined as the difference (in $\mathrm{dB}$ ) between the effective transmitted power and the received power. In UMa, PL is mainly caused by free-space loss, penetration loss, foliage loss, and oxygen absorption (dry or moist air). The free-space path loss depends on the locations of both BS and MS and incorporates effects of reflection, refraction, and diffraction. In UMa, later are usually caused by static infrastructure as well as dynamical objects such as vehicles and crowds.

Channel Model. The clustered delay line (CDL) channel model was proposed in 3GPP TR38.901 (3GPP Radio Access Network Working Group) for link-level simulations. The full carrier frequency ranges from $500 \mathrm{MHz}$ to $100 \mathrm{GHz}$ with a maximum channel bandwidth of $2 \mathrm{GHz}$. It was a geometry-based stochastic MIMO channel model. It was designed for the small-scale fading process. TR38.901 offers five channel profiles named CDL-A, CDL-B, CDL-C, CDL-D, and CDL-E. The first three represent Non-Line-Of-Sight (NLOS) scenarios, while the rest correspond to Line-Of-Sight (LOS) scenarios.

The importance of the CDL channel model has been proven in technical report R1-165974 3GPP, which consists of calibration results from leading 5 G pioneers such as Ericsson, Huawei, Samsung, and Nokia to name a few. 
$\mathrm{CDL}$ is a comprehensive channel model that encompasses time, frequency, space, and polarization dimensions. It is continuous in time as the transmitter or receiver is moving, which gives time selectivity by Doppler spread. It further contains diffuse phenomena by including subpaths around the dominant path. CDL has rich resolvable multipath components for $5 \mathrm{G}$ wideband transmission, which characterizes frequency selectivity. Delay spreads for various scenarios, from indoor to outdoor cases, are tabulated. Considering radio wave propagation, CDL models incoming paths (also known as rays) on a cluster-wise basis. Besides, angular spreads for both azimuth and zenith directions are also included. Moreover, CDL supports a large antenna array for which the power pattern for each antenna is accompanied. A more detailed performance evaluation can be found in Servetnyk M.

Transmit array. With an increased number of transmit antennas, beamforming is a versatile technique to improve signal transmission. In wireless communications, the goal of beamforming is to increase the signal power at the intended user and reduce interference to non-intended users. Simply put, beamforming allows for a radio signal to be focused on its target, while shifted away from the victims. The larger number of transmit antennas are used, the higher gain can be obtained. This is illustrated via Fig. 1 below. For $4 \times 4$ transmit array, nearly $10 \mathrm{dBi}$ gain can be obtained, while for $16 \times 16$ array gain could reach up to $30 \mathrm{dBi}$.

Notably, (Shehata M., 2019) has shown that employing state-of-art analog beamforming method spectral efficiency improves with an increased number of transmit antennas. However, in high signal-to-noise ratio (SNR) regions, performance saturation can be observed. Specifically, for $8 \times 8$ and $16 \times 16$ uniform rectangular arrays (URA), spectral efficiency does not improve after SNR equal to $10 \mathrm{~dB}$ and $20 \mathrm{~dB}$, respectively. Saturation effect has no place to be with the hybrid beamforming schemes (Molisch A. F., 2017) to be exploited. However, computation complexity arose from using this large number of antennas still precludes hybrid beamforming usage.

For reasons above, transmit arrays with size below $16 \times 16$ antennas with analog beamforming steering are used in evaluations in this work.

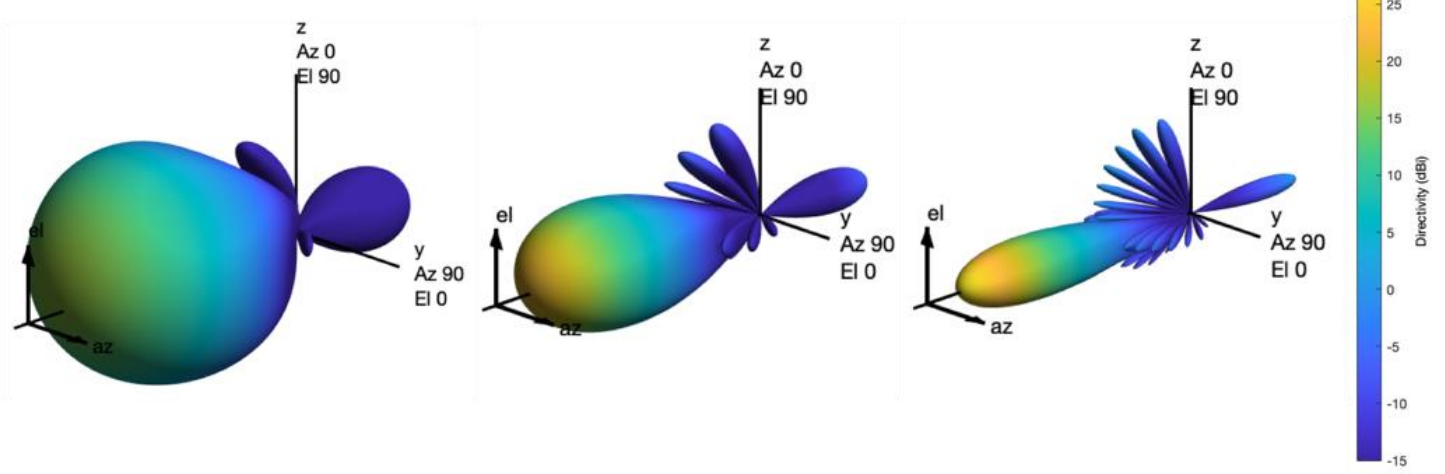

Figure 1 - The radiation pattern of the Tx antenna corresponding to (left to right) $4 \times 4,8 \times 8,16 \times 16$ arrays

Performance Metrics: Coverage, SINR, and Channel Capacity. In mobile networks, coverage is defined as the ability of an MS to decode signal sent from BS and guarantee certain QoS. Coverage depends on the received signal power, also known as link budget, which in return depends on both transmit power, interference, BS and MS antenna gains, and PL. For UMa link budget can be calculated as

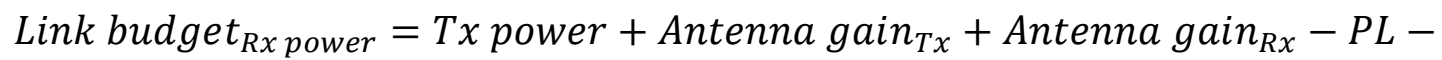
Slow fading margin - Interf. margin - Noise margin - Oxygen absorption Penetration Loss . 
Next, this number is compared with receiver sensitivity, and if it exceeds a threshold, then the successful transmission is possible.

SINR is a quantity used to give theoretical upper bounds on channel capacity in wireless communication systems such as networks and defined as

$$
S I N R=\frac{R x \text { power }}{\text { Interference power }+ \text { noise power }} \text {. }
$$

Herein, we assume that MS is attached to the BS that results in strongest received signal power, and therefore signals from other BSs are treated as interference. Given SINR, the upper bound channel capacity $C$ can be calculated with Shannon's equation

$$
C=B \times \log _{2}(1+S I N R),
$$

where $B$ denotes signal bandwidth.

To summarize, system performance is dependent on three features: ISD, operating frequency, and transmit array size. With the facilitation of performance metrics, the optimal combination can be found via experiments described in the next section.

\section{Problem statement}

A combination of the abovementioned parameters, namely, operating frequency, antenna array size, and ISD, plays a significant influence on overall system performance and hence requires detailed analysis and evaluations. A trade-off between network densification and interference caused by improved signal strength over serving links is not presented clearly for a real-world scenario.

\section{Results}

Experimental setup. The considered urban macrocell environment is the city center of Kyiv, Ukraine, and is depicted in Figs. 2 and 3. 19 BS sites were selected that emulate a realistic cellular deployment topology of 57 cells, as shown in Fig. 4. At each BS, the antenna array transmits a linearly-polarized signal. The MS consists of a single dipole antenna. The rest of the parameters are specified in Table 1.

Table 1 - Parameters dipole antenna

\begin{tabular}{|c|c|}
\hline Parameter & Value \\
\hline Center site location & {$[50.449698,30.524004]$} \\
\hline Operating scenario & UMa, Outdoor, LoS/NLoS \\
\hline ISD & $50-200 \mathrm{~m}$ \\
\hline Operating frequencies & $3.5,28,38 \mathrm{GHz}$ \\
\hline \# Cell Sites & 19 \\
\hline \# Cells & 57 \\
\hline Tx array/size & URA, half-wave spacing $4 \times 4,8 \times 8,16 \times 16$ \\
\hline ISD & $15 \mathrm{~m} / 1.5 \mathrm{~m}$ \\
\hline Tx/Rx height & $20 \mathrm{MHz}$ \\
\hline Bandwidth & $-114 \mathrm{dBm}$ \\
\hline Noise power & $6 \mathrm{~dB}$ \\
\hline Slow margin fading & $7 \mathrm{~dB}$ \\
\hline Foliage loss & $0 \mathrm{~dB} @ 3.5 \mathrm{GHz}, 3 \mathrm{~dB} @ 28,38 \mathrm{GHz}$ \\
\hline Oxygen absorption & \\
\hline
\end{tabular}




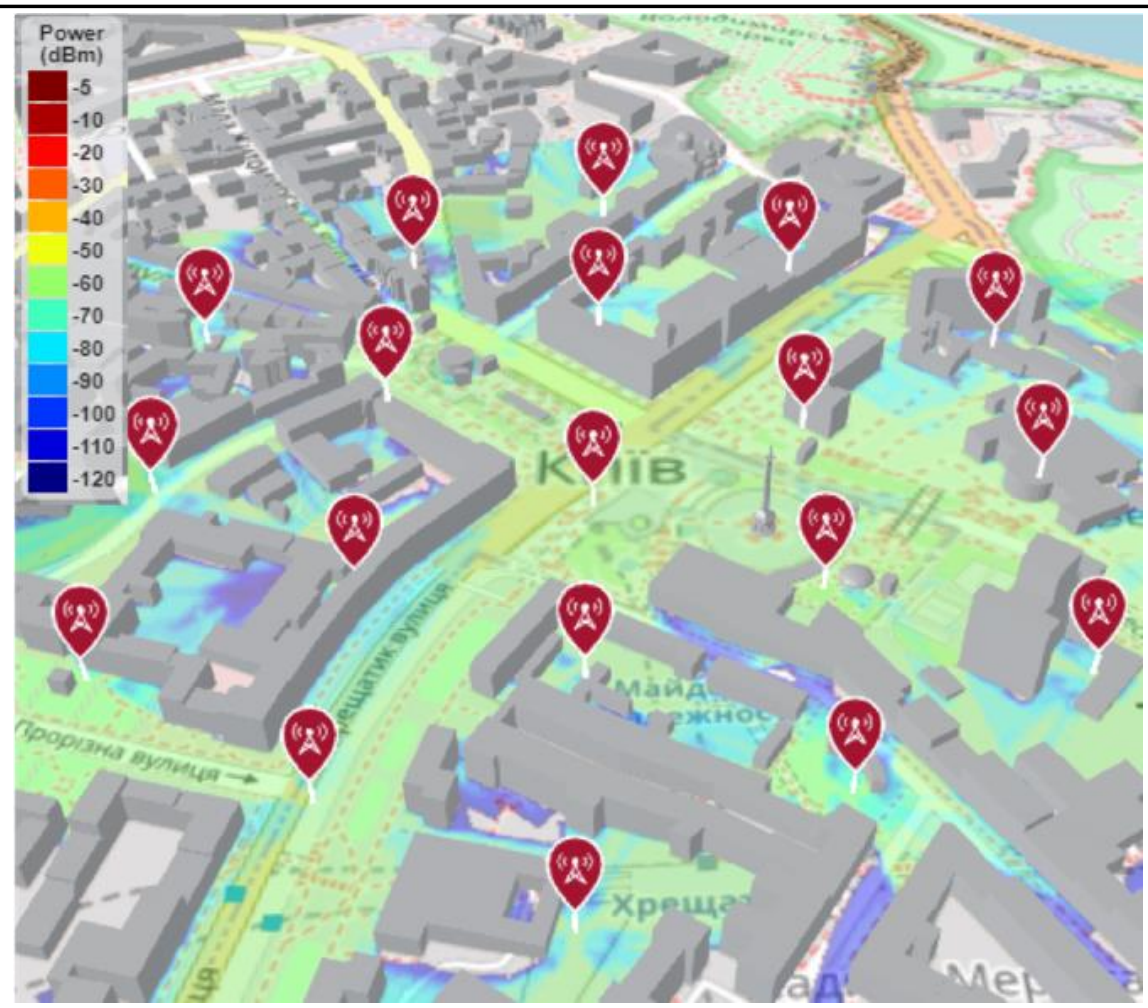

Figure 2 - Coverage map for $\mathbf{8} \times \mathbf{8}$ array @28GHz.

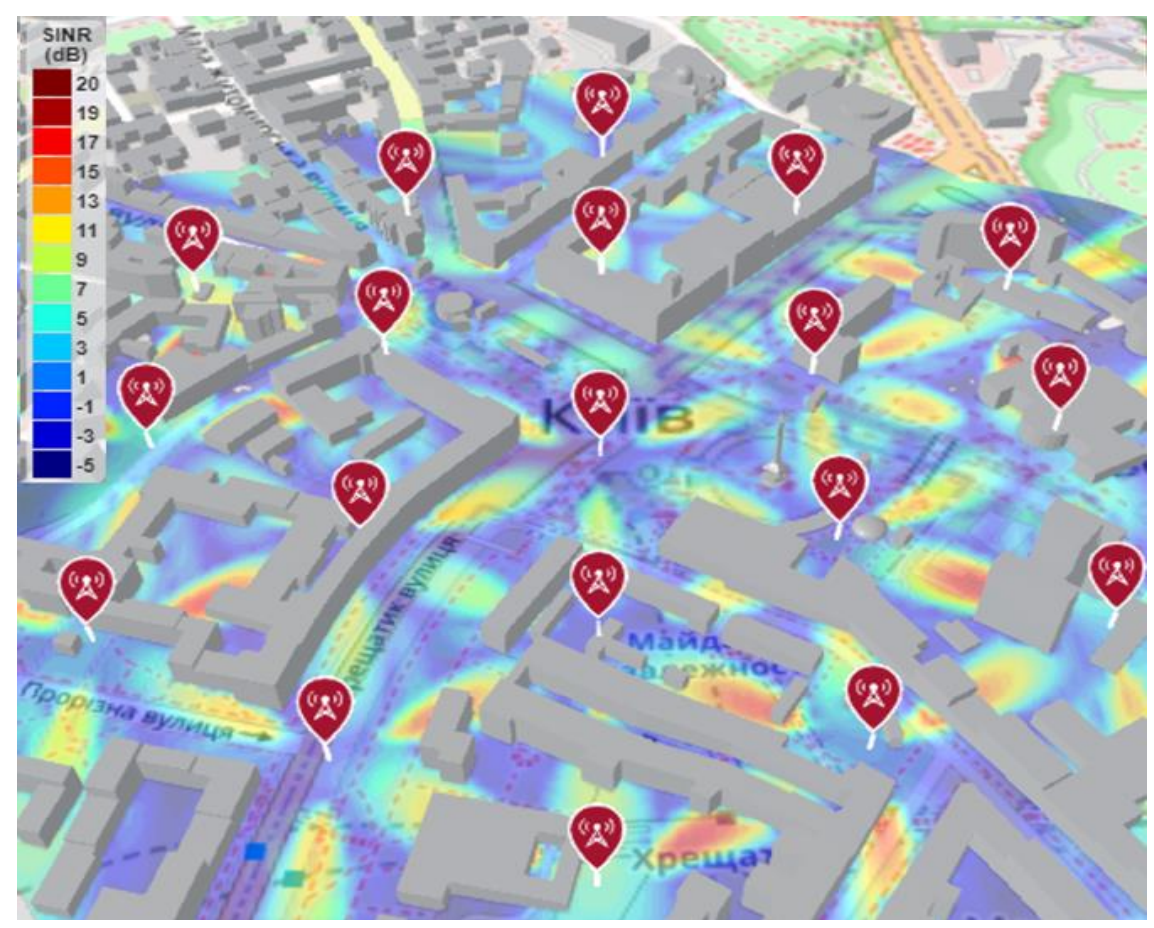

Figure 3 - SINR map for $\mathbf{8} \times \mathbf{8}$ array @28GHz. 


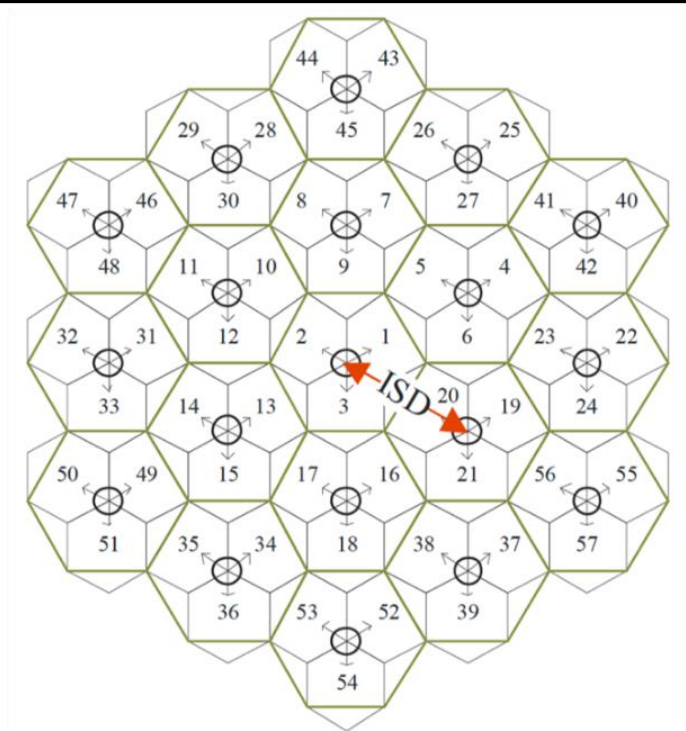

Figure 4-Simulated Network Layout

\section{Discussion}

Presented in this section are simulations and evaluations of various transmitter configurations performance.

In the first experiment, the dependency of coverage for different ISD and transmit array size is investigated and shown in Fig. 5. As expected, the received signal power level decreases with an increase in operating frequency and ISD. This is a result of the PL domination. In addition, it is possible to observe how increased transmit array size is able to compensate for high PL of mmWave channel. Particularly, coverage of $4 \times 4$ array at $3.5 \mathrm{GHz}$ is close to one of the $8 \times 8$ array at $28 \mathrm{GHz}$ and to the $16 \times 16$ array at $38 \mathrm{GHz}$ at ISD greater than $150 \mathrm{~m}$.

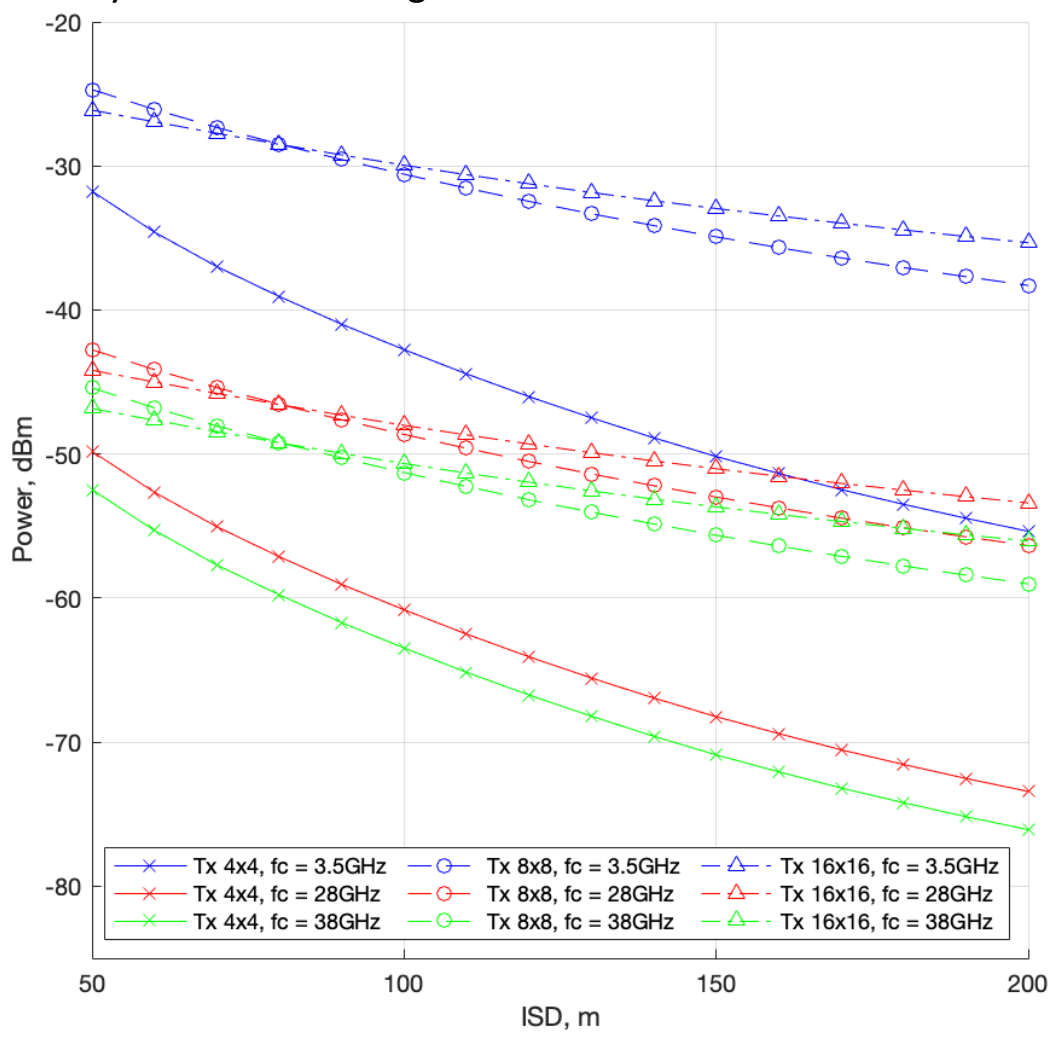

Figure 5 - Mean signal level at the receiver for different ISD 
In the second experiment, peak supported data rate or channel capacity for various ISD is shown, and is depicted in Fig. 6. Clear separation between curves corresponding to different transmit array size can be seen. This difference is proportional to the number of antennas. Specifically, there is two times difference in capacity between $4 \times 4$ and $8 \times 8$ arrays and four times between $4 \times 4$ and $16 \times 16$ arrays. A particular difference between operating frequencies is not observed because the same bandwidth is assumed for different frequencies. However, in the actual scenario, operators are able to allocate a larger bandwidth at higher frequencies.

Another result of the experiment is the clear existence of the peak in the rate curves, which can bring to a conclusion of the appropriate ISD. Noticeably, this peak is narrow for large antenna arrays, while much broader for smaller arrays. Peak exists because if ISD is small, then intercell interference prevails, while for larger ISD, then received signal power is small, and transmission becomes noise limited.

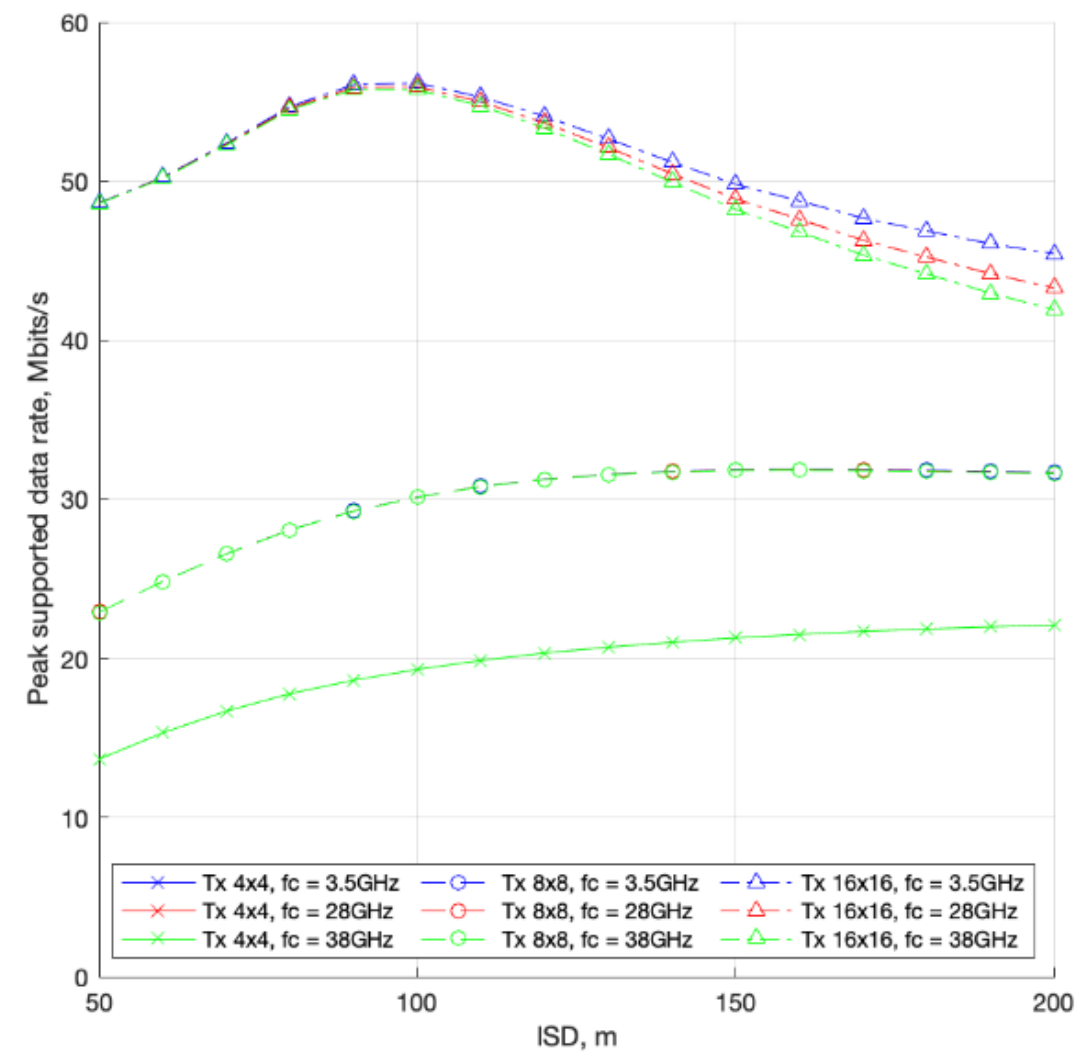

Figure 6 - Average peak supported data rate for different ISD

To summarize, simulations above show a clear trade-off between transmit antenna array size, operating frequency, and ISD. For mmWave frequencies combination of these parameters becomes essential and is able to reach high gain for large antenna arrays.

\section{Conclusions}

In this work evaluation of the impact of ISD, antenna array size, and operating frequency on link budget, coverage, and achievable rate in urban macrocell scenario is presented. Simulations are conducted in the environment of Kyiv city center, which will expect to deploy 5G system in 2022-2025.

MmWave communications have shown to be more sensitive to combination of transmitter parameters and, hence, a useful guideline has been provided to evaluate suitable deployment configuration that leads to significant performance gain. This work serves as a roadmap for $5 \mathrm{G}$ system deployers, particularly mobile operators. Experiments align with theoretical provisions and give important qualitative baseline. 


\section{Funding}

This study received no specific financial support.

\section{Competing interests}

The authors declare that they have no competing interests.

\section{References}

1. Mumtaz, S., Rodriguez, J., and Dai, L., "MmWave Massive MIMO: A Paradigm for 5G," Academic Press, 2016.

2. 3GPP Radio Access Network Working Group et al., "Study on channel model for frequencies from 0.5 to $100 \mathrm{GHz}$ (release 15)," Tech. Rep., 3GPP TR 38.901, 2018.

3. MacCartney, G.R., Zhang, J., Nie, S., and Rappaport, T.S., "Path loss models for $5 \mathrm{G}$ millimeter wave propagation channels in urban microcells," IEEE Global Communications Conference (GLOBECOM), pp. 3948-3953, 2013.

4. Roh, W., et al., "Millimeter-wave beamforming as an enabling technology for $5 \mathrm{G}$ cellular communications: Theoretical feasibility and prototype results," IEEE communications magazine, vol. 52, no. 2, pp. 106-113, 2014.

5. Ge, X., et al., "5G ultra-dense cellular networks," IEEE Wireless Communications, vol. 23, no. 1, pp. 72-79, 2016.

6. Landström, A., Jonsson, H., and Simonsson, A., "Voronoi-based ISD and site density characteristics for mobile networks," IEEE Vehicular Technology Conference (VTC Fall), 2012.

7. Hou, H.-A., and Wang, L.-C. "Area spectral efficiency for cellular networks with small reuse distance: An algebraic approach," IEEE 26th Wireless and Optical Communication Conference (WOCC), 2017.

8. Andrews, J., Baccelli, F., and Ganti, R., "A tractable approach to coverage and rate in cellular networks," IEEE Transaction on Wireless Communications, vol. 59, no. 11, pp. 3122-3134, Nov. 2011.

9. Kountouris, M., "Performance limits of network densification," IEEE Journal on Selected Areas in Communications, vol.35, no. 6, pp. 1294-1308, 2017.

10. Rappaport, T. S., et al. "Millimeter wave mobile communications for $5 \mathrm{G}$ cellular: It will work!," IEEE access, vol. 1, pp. 335-349,

\section{Cписок використаних джерел}

1. Mumtaz, S., Rodriguez, J., and Dai, L., "MmWave Massive MIMO: A Paradigm for 5G," Academic Press, 2016.

2. 3GPP Radio Access Network Working Group et al., "Study on channel model for frequencies from 0.5 to $100 \mathrm{GHz}$ (release 15)," Tech. Rep., 3GPP TR 38.901, 2018.

3. MacCartney, G.R., Zhang, J., Nie, S., and Rappaport, T.S., "Path loss models for 5G millimeter wave propagation channels in urban microcells," IEEE Global Communications Conference (GLOBECOM), pp. 3948-3953, 2013.

4. Roh, W., et al., "Millimeter-wave beamforming as an enabling technology for $5 G$ cellular communications: Theoretical feasibility and prototype results," IEEE communications magazine, vol. 52, no. 2, pp. 106-113, 2014.

$5 . \mathrm{Ge}, \quad \mathrm{X}$., et al., "5G ultra-dense cellular networks," IEEE Wireless Communications, vol. 23, no. 1, pp. 72-79, 2016.

6. Landström, A., Jonsson, H., and Simonsson, A., "Voronoi-based ISD and site density characteristics for mobile networks," IEEE Vehicular Technology Conference (VTC Fall), 2012.

7. Hou, H.-A., and Wang, L.-C. "Area spectral efficiency for cellular networks with small reuse distance: An algebraic approach," IEEE 26th Wireless and Optical Communication Conference (WOCC), 2017.

8. Andrews, J., Baccelli, F., and Ganti, R., "A tractable approach to coverage and rate in cellular networks," IEEE Transaction on Wireless Communications, vol. 59, no. 11, pp. 3122-3134, Nov. 2011.

9. Kountouris, M., "Performance limits of network densification," IEEE Journal on Selected Areas in Communications, vol.35, no. 6, pp. 1294-1308, 2017.

10. Rappaport, T. S., et al. "Millimeter wave mobile communications for $5 \mathrm{G}$ cellular: It will work!," IEEE access, vol. 1, pp. 335-349, 
2013.

11. Busari, S. A., et al. "Millimeter-wave massive MIMO communication for future wireless systems: A survey," IEEE Communications Surveys \& Tutorials, vol. 20, no. 2 pp. 836869, 2017.

12. Servetnyk, M. and Hsiao, W.-H., "Performance Evaluation of Polarization Effects on $5 \mathrm{G}$ Clustered Delay Line Channels", under review.

13. Shehata, M., Crussière, M., and Hélard, M., "On the Theoretical Limits of Beam Steering in mmWave Massive MIMO Channels," IEEE 30th Annual International Symposium on Personal, Indoor and Mobile Radio Communications (PIMRC), 2019.

14. Molisch, A. F., et al. "Hybrid beamforming for massive MIMO: A survey," IEEE Communications Magazine, vol. 55, no. 9, pp. 134-141, 2017.

\section{3.}

11. Busari, S. A., et al. "Millimeter-wave massive MIMO communication for future wireless systems: A survey," IEEE Communications Surveys \& Tutorials, vol. 20 , no. 2 pp. 836 869, 2017.

12. Servetnyk, M. and Hsiao, W.-H., "Performance Evaluation of Polarization Effects on $5 \mathrm{G}$ Clustered Delay Line Channels", under review.

13. Shehata, M., Crussière, M., and Hélard, M., "On the Theoretical Limits of Beam Steering in mmWave Massive MIMO Channels," IEEE 30th Annual International Symposium on Personal, Indoor and Mobile Radio Communications (PIMRC), 2019.

14. Molisch, A. F., et al. "Hybrid beamforming for massive MIMO: A survey," IEEE Communications Magazine, vol. 55, no. 9, pp. 134-141, 2017. 